\title{
Maternal diabetes amplifies the influence of maternal asthma and smoke exposure on the development of asthma in offspring
}

\author{
Meghan B Azad ${ }^{1 *}$, Allan B Becker ${ }^{2}$, Anita L Kozyrskyj ${ }^{1}$ \\ From Canadian Society of Allergy and Clinical Immunology Annual Scientific Meeting 2011 \\ Quebec, Canada. 20-23 October 2011
}

\section{Background}

Perinatal programming is an emerging theory for the fetal origins of chronic disease. Maternal asthma and environmental tobacco smoke (ETS) are two of the bestknown triggers for the perinatal programming of asthma, while the potential role of maternal diabetes has not been widely studied. The goal of this study was to determine if maternal diabetes contributes to the perinatal programming of asthma, and if so, whether its effect is additive or synergistic with respect to ETS exposure and maternal asthma.

\section{Methods}

We studied 3,574 Canadian children, aged 7-8 yr, enrolled in a population-based birth cohort. Standardized questionnaires were completed by the children's parents, and data were analyzed by multivariate logistic regression.

\section{Results}

Asthma was reported in 442 children (12.4\%). Asthmatic children were more likely to have mothers, but not fathers, with diabetes. In children without maternal history of diabetes, ETS exposure increased the risk of child asthma by 1.4-fold (adjusted odds ratio, 1.40; $95 \%$ confidence interval, 1.13-1.73), while maternal asthma increased risk by 3.6 -fold (3.59; 2.71-4.76). In children born to diabetic mothers, these effects were amplified to 5.7 -fold (5.68; 1.18-27.37) and 11.3-fold (11.30; 2.26$56.38)$, respectively. There was no independent effect of maternal diabetes after adjusting for maternal asthma and ETS exposure (OR 0.65, 95\%CI 0.16-2.56).

${ }^{1}$ Women and Children's Health Research Institute, Department of Pediatrics, University of Alberta, Edmonton, Canada

Full list of author information is available at the end of the article

\section{Conclusions}

Maternal diabetes contributes to the perinatal programming of child asthma by amplifying the detrimental effects of ETS exposure and maternal asthma.

\section{Author details}

'Women and Children's Health Research Institute, Department of Pediatrics, University of Alberta, Edmonton, Canada. ${ }^{2}$ Department of Pediatrics and Child Health, University of Manitoba, Winnipeg, Canada.

Published: 14 November 2011

doi:10.1186/1710-1492-7-S2-A22

Cite this article as: Azad et al: Maternal diabetes amplifies the influence of maternal asthma and smoke exposure on the development of asthma in offspring. Allergy, Asthma \& Clinical Immunology 2011 7(Suppl 2):A22
Submit your next manuscript to BioMed Central and take full advantage of:

- Convenient online submission

- Thorough peer review

- No space constraints or color figure charges

- Immediate publication on acceptance

- Inclusion in PubMed, CAS, Scopus and Google Scholar

- Research which is freely available for redistribution

Submit your manuscript at www.biomedcentral.com/submit
C Biomed Central 